\title{
加藤弘之の宗教批判と進化論について \\ The religious critique of Hiroyuki Kato and his evolutionary thought
}

\section{葛奇蹊 \\ 国際関係学院（北京）}

\section{要旨}

加藤弘之は明治時代の思想界を風靡した代表的な人物であり、進化論を援用して、 中央集権的な国家体制への絶対的服従を一般民衆に要求したことでよく知られている。 その国家主義的な立場を擁護するために進化論を援用した加藤の思想的営為の一環と して、彼の宗教批判が挙げられる。本研究では「宗教と科学」という分析視角を手掛 かりに、明治時代の「宗教」を代表するキリスト教・仏教と明治時代の「科学」を代 表する進化論の間にいかなる融合・衝突が起きたのかという問題を、加藤弘之の宗教 批判を中心に考察する。

キーワード :

宗教と科学、進化論、キリスト教批判、仏教批判 


\section{葛奇蹊 \\ 国際関係学院（北京）}

\section{1. 序言}

“宗教与科学” 的关系问题可以说是贯穿明治时期日本思想界的一条主线, 因 为在日本明治维新后积极吸收欧美先进科技和文化的大背景下, 知识分子们势必面 临着如何看待随之同时传入的宗教一特别是基督教的课题, 也必须思考如何调和 “宗 教与科学” 这对根本对立的矛盾, 使之与日本的近代化发展相适应。明治时代的著 名神学家、日本组合基督教会会长小崎弘道的如下一番话可谓是对这一情况的真实 反映:

我国（日本一笔者注，下同）的信徒首先遭遇的是 “基督教与科学的关系” 问 题。基督教最初是与泰西的文物机械、科学工艺一起传入我国的。然而从一方面来 看, 科学与基督教所讲的内容全然相反, 看起来难以并行不悖。尤其是在当时的欧 美, 新科学日益兴盛、纵横无忌, 不少科学家无视基督教, 对其持怀疑态度, 这种 风潮当然也传入了我国。并且维新前后, 我国的知识分子大多对基督教怀有难以抹 去的偏见和厌恶, 因此他们希望将西洋的科学与基督教全然区分开来, 只引进前者, 而排斥后者。

特别是在达尔文的进化论思想被介绍到日本之后，这种将欧美的科技与宗教区 别对待、在吸收上持双重标准的主张在日本的思想界中越发明显。正如《物种起源》 刚出版后在英国遭到传统宗教思想的抵触从而引发了科学家与宗教者之间的论争一 样 ${ }^{2}$, 进化论在日本也被很多思想家视为 “科学” 的代名词, 他们将其作为对宗教进 行批判和攻击的有力武器。就连把进化论介绍到日本的莫尔斯 (Edward S. Morse) 也在《动物进化论》中明确提到他在东京大学开设进化论课程的初衷是为了揭露宗 教的非科学性:

小崎弘道: 「基督教の本質」, 『小崎全集』第一卷, 小崎全集刊行会, 1938 年, 第 9 10 页。

“1859 年 11 月 24 日, 『物种起源』出版。(中略) 除了几名年轻科学家表示支持之外, 大多数人开 始的反应都是否定的, 据说一位牧师给达尔文冠以 “英国最危险分子” 的名字。不必惊讶于保守派 展开了多么激烈的反击, 因为进化论威胁到了宗教一特别是被视为既有社会支柱的教会的利益。反 对进化论的科学争论此起彼伏, 其中的一些争论对于达尔文和他的支持者们来说成为了重大的问 题。” Peter J. Bowler 著、鈴木善次等译: 『進化思想の歴史』, 朝日新聞社, 1987 年, 第 303 页。 
宗教的信者身处空中楼阁, 痴人说梦, 将邪教妖妄之说布于天下, 阻塞生民耳 目, 陷天下于污浊, 甚至高才明智之人也受其污染, 深醉其迷溺之中不醒, 从生到 死浑然不觉。(我) 宣讲此进化论学说就是为了驳斥宗教。宗教终归只是正道上的䔉 䒪, 时值今日开明之世, 应开辟正道的塞茅, 排却邪诞妖妄, 不让变迁进化之论落 后于其他日益精覆的学术, 此为学者专务。 ${ }^{3}$

反之, 以内村鉴三、小崎弘道为代表的基督教徒则试图证明基督教与进化论不 存在根本对立。对于内村鉴三来说, 进化论是真理, 坚持进化论有助于人们更好地 理解基督教, 但进化论只不过是对世间万物进行解释说明的一种方法, 基督教才是 不依附于进化论的绝对真理, 二者都以实现真理为目标。基督教关注的是造化的结 果, 进化论关注的是实现这种结果的手段方法, 两者在原理上根本不矛盾。 ${ }^{4}$ 小崎弘 道则在此基础上更进一步, 认为进化法则是神创造世界的一种手段, 是神在创造世 界伊始赋予自然界的理法, 尔后的天地发展都遵循这种理法, 进化法则不过是神的 动作的延续。一言以蔽之, 进化法则和世界一样是神的创造物, 不仅不与基督教存 在矛盾, 还能够促进宗教观的变化发展, 加深对宗教的理解。 ${ }^{5}$ 因此, “现今的大问题 不在于调和进化论与有神论的关系, 而在于怎样将进化的规律应用到基督教的教理 之中。” ${ }^{6}$

“宗教与科学” 的关系问题在明治时代产生重大影响的另外一个原因在于佛教。 江户时代后期, 佛教势力开始从内部瓦解, 逐渐呈现出衰退的迹象。特别是到了明 治维新以后, 政府通过颁布神佛分离令、开展废佛毁释运动, 逐步建立起了国家神 道体制; 另一方面, 基督教势力不断扩张, 明治六（1873）年明治政府撤消切支丹

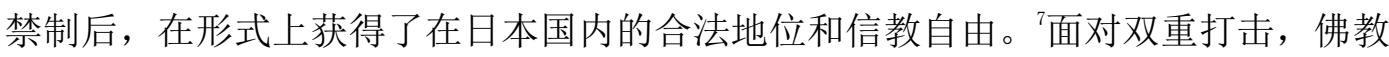
几乎陷入了濒临灭亡的境地。井上圆了曾经慨叹佛教如果持续低迷衰落的趋势, 在 “适者生存” 的进化法则中迟早无法避免灭亡的命运 ${ }^{8}$ 。于是佛教徒希望通过进化论

3 Edward S. Morse 著、石川千代松译:「動物進化論」, 明治文化研究会編:『明治文化全集』第 27 卷 (科学編), 日本評論社, 1967 年, 第 362 页。

4 内村鑑三:「進化論と基督教」,『内村鑑三全集』第 27 卷, 岩波書店, 1980 1983 年, 第 $244 \sim 245$ 页。

5 “由此吾人不仅可以更方便地解释神学上的问题, 还可以加深宗教体验, 激励信仰。” 小崎弘道:「我 国の宗教及道徳」,『小崎全集』第三卷，第 488 页。

6 同上, 第 480 页。

7 梁明霞:「近代日本新佛教运动研究」, 北京大学博士学位论文, 2011 年, 第 1 页。

8 “在社会进化的大背景下, 从当时流行的进化论思想来看, 如果按照今日的趋势发展下去, 竞争变 化、适种生存、自然淘汰的规则必然会让佛教难逃绝灭的命运。”常盤大定：「『真理金針 (初篇)』 解題」, 明治文化研究会编: 『明治文化全集』第 11 卷 (宗教編), 日本評論社, 1928 年, 第 32 页。 
来证明佛教的科学性, 从而度过难关。佛教教团内部陆续出现了像井上圆了、清泽 满之等积极鼓吹佛教与进化论融合的佛教徒。因此, 佛教徒们也必须像基督教徒一 样，去探求以进化论为代表的科学与佛教之间的关系。

尽管如此, 宗教与以进化论为代表的科学之间的融合并非一帆风顺, 因为明治 时代的基督教和佛教不仅要在国家神道的体制之下艰难地谋求生存和发展, 同时还 在相当长的一段时期内遭受过来自国家主义者从国体论和教理两个层面展开的批判 和攻击。其中最具代表性的一个例子是进化论的代言人加藤弘之的宗教批判, 进化 论与宗教之间的激烈碰撞在加藤弘之与宗教者之间的论争中体现得淋漓尽致, 并且 加藤弘之的宗教批判在一定程度上对之后的宗教批判论产生了决定性的影响 ${ }^{9}$ 。然而 历来的研究比较倾向于探讨加藤弘之如何从国体论的角度来批判宗教以及双方争论 的过程 ${ }^{10}$, 对于 “其从进化论思想的角度对宗教教理进行的批判以及进化论思想在其 宗教批判中和他与宗教界的论争中所发挥的作用” 没有给予充分的关注, 尽管他当 时已经步入晚年, 是一个思想比较成熟的进化论者, 其宗教批判的内容也基本立足 于进化论的框架之上 ${ }^{11}$ 。因此, 本文将对这个问题进行重点探讨。

\section{2. 加藤弘之的宗教観}

日本哲学家永田广志曾在其论文 “明治时代宗教批判的特质” 中将明治时代的 宗教批判分为三种类型, 认为第二种类型一即以加藤弘之、井上哲次郎等人为代表 的国家主义者的宗教批判是日本宗教批判史上最具特色的一类。 ${ }^{12}$ 加藤弘之以其尖酸 辛辣的宗教批判而著称, 不过在探讨其宗教批判之前, 首先需要了解他的宗教观, 下面一段话可以体现出他对宗教的基本态度:

我认为基督教对于吾国体有大害，所以欲以科学的方法来证明其理由。不仅基 督教，但凡一切宗教，不问是何宗派，我都不以为然。因为任何宗教都会带给我们 迷信，妨碍知识的进步。佛教以自身的信仰为正信，其他一切宗教信仰为迷信; 基 督教也以自身的信仰为正信, 其他一切宗教信仰为迷信。其他的宗教也一样, 都主 张自身的信仰, 排斥其他信仰。但各种宗教所鼓吹的正信都无不属于迷信, 宗教彼 此之间的争斗不过是迷信与迷信的较量。因此吾辈希望知识进步的人终归无法相信

9 吉田曠二: 『加藤弘之の研究』, 大原新生社, 1976 年, 第 122 页。

10 例如, 田畑忍: 『加藤弘之』, 吉川弘文館, 1959 年; 吉田曠二: 『加藤弘之の研究』, 大原新生社, 1976 年，等等。

11 同 9, 第 124 页。

12 永田広志:「明治時代における宗教批判の特質一『日本ブルジョア唯物論者』続編」,『永田広志 選集第四卷 日本哲学思想史』, 白揚社, 1948 年, 第 413 页。 
任何宗教。13

加藤弘之的宗教观可以概括为 “宗教是迷信, 并对日本的国体有很大害处”, 具 体来说包括两个方面: 一、首先从国体论的角度来看, 宗教的主张与以天皇制为中 心的中央集权国家体制相矛盾, 会危害国家的统治基础。并且宗教与国家本来就是 非此即彼甚至水火不相容的关系，信宗教就无法忠于国家，忠于国家就会违背教义; 二、从教理角度来看，宗教是 “迷信”，与 “正信” 相对立。“正信” 指的是对已知 事物的信奉, 而迷信则是对未知事物的信奉。宗教鼓吹人们去信奉未知的、没有被 证明实际存在的事物, 有碍于 “知识的进步” ${ }^{14}$ 。不过, 加藤弘之对宗教的批判只停 留在理论层面, 并没有提出反对宗教的具体主张, 因为他认识到宗教的存在具有一 定的现实性和必要性。

虽然我如此卖力地论证宗教信仰的有害之处，但遗憾的是这种有害的信仰在某 种意义上来说或多或少是必要的。这绝非我的本意, 但确实是没有办法的事情。因 为在古代, 知识水平极其低下; 不仅如此, 即使在今天的开明世界, 下层社会不通 事理的无知者仍占据多数。(中略) 对待这些人就不得已地要使用诸如妖怪幽灵、神 佛慈悲赏罚等较易理解的概念来抚慰其心灵。(中略) 况且随着开明进步而逐渐进化 至今天的佛教阿弥陀或基督教的唯一真神已经是最高级的妖怪幽灵了。

此外, 他也承认宗教具有积极的一面, 即从古至今宗教在慈善事业方面为社会 做出过很多贡献, 但 “这些关乎的都是物质方面, 并非精神方面, 对于以精神为本 的宗教来说只算得上是副业, 总体来说宗教产生的消极结果要大于积极结果” ${ }^{16}$, 可 见他对宗教的基本态度是批判的、否定的。

那么, 他的宗教批判到底立足于怎样的基础之上? 换句话说, 是什么因素决定 了他对宗教持有绝对的否定态度, 他又是根据什么理论来证明自己的观点的? 在笔 者看来, 加藤弘之宗教批判的理论前提之一在于他的进化论思想, 具体来说是以进 化论思想为基轴的有机体学说和一元主义。首先, 他参照德国的进化论者海克尔

(Ernst Haecke1，1834 1919) 的国家有机体学说, 认为自然界和人类社会有机体 的存在形式分为由低到高的三个阶段一单细胞的有机体 (细胞体)、复细胞的有机体 (生物个体) 和复复细胞的有机体 (社会群体)。每一个更高阶段的有机体都由多个 低阶段的有机体组合而成, 自然界和人类社会都始终遵循从低阶段的有机体向高阶 段的有机体不断进化的规律。 ${ }^{17}$ 而国家作为人类社会现阶段进化发展的最高形式，拥

\footnotetext{
13 加藤弘之: 『吾国体と基督教』, 金港堂, 1907 年, 第 $1 \sim 2$ 页。

14 同上, 第 8 页。

15 同上, 第 $13 \sim 15$ 页。

16 同上, 第 18 页。

17 加藤弘之: 『自然界の矛盾と進化』, 金港堂, 1906 年, 第 67 68 页。
} 
有至高无上的地位, 组成国家这个有机体的 “臣民” 都要以服从国家意志为行动准 则, 以维护国家统一和国家利益为最高目标。 ${ }^{18}$ 因此, 诸如佛教、基督教这些倡导全 人类平等、以个人灵魂的救济为终极目标的世界宗教与国家在根本上存在冲突, 必 然成为加藤弘之极力批判的对象。

其次, 加藤弘之将所有宗教归为 “迷信” 的哲学根据来源于以进化论思想为支 撑的一元主义。根据他的说法, 一元主义又称因果主义, 指的是宇宙只有一个本源 即因果法则 (自然法), 万事万物的产生、发展、灭亡都受这个自然法的支配, 都是 原因和结果的必然联系, 加藤弘之认为这种因果主义已经通过进化论得到了 “科学 的证明” ${ }^{19}$ 。与此相对的是二元主义或称为目的论, 这种观点认为在自然法的范围之 外还有一种超自然的法则或意志, 这种超自然的法则或意志可以自由自在地支配宇 宙的发展变化, 世间万物都是为了达到某种目的而被超自然的法则或意志创造出来 的, 其发展和变化也是为了合乎一定的目的, 基督教的唯一神就是这种观点的典型 例子。加藤弘之认为这种目的论经进化论证明是错误的, 因为目的会随着进化阶段 的不同而发生变化, 并非最初被设定后就一成不变, 而进化本身就是因果法则的产 物。宗教属于迷信就是因为它教唆人们去相信神秘未知的或未经证实的超自然的事 物, 以致于陷入所谓的二元主义泥潭之中 ${ }^{20}$ 。

对于宗教在当时社会非常盛行的情况应该如何应对, 加藤弘之也有自己的看法, 简而言之可以用 “现状维持” 这四个字来概括。如前所述, 他对宗教持有绝对的否 定态度, 但也不得不承认宗教将长期存在的现实性, 并且在一定程度上还在发挥着 积极的作用一即宗教可以通过浅显易懂的说教方式让知识水平低下的阶层和心智尚 未发育成熟的孩童信服, 达到安身立命、稳定社会的效果, 而社会上总会存在知识 水平低下的阶层和心智尚未发育成熟的孩童, 因此让宗教从这个世界上消失是不现 实的 ${ }^{21}$ 。另一方面, 针对一些学者提出的 “对宗教施行改革, 逐步去除其迷信的成分, 创立符合科学精神的宗教” 的主张, 加藤弘之明确表示反对。在他看来, 社会不仅 不需要 “迷信的宗教”, 也不需要 “科学的宗教”, 因为社会无法孕育出拥有足够能 力创立科学宗教的 “大英杰”, 而真正拥有科学求真精神、专心于学问研究的人也不 会寄希望于通过宗教来获得真理。既然宗教既无法消灭, 又无法通过改革剔除其迷

18 同 16 , 第 22、27 页。

19 同 17 , 第 21 页。

20 同 18 , 第 $9 \sim 10$ 页。

21 加藤弘之: 所謂将来の宗教に就て」, 『加藤弘之講演全集』( 以下简称为『講演全集』) 第三册, 丸善株式会社, 1900 年, 第 207 页。 
信要素, 那么也只有以一种消极的姿态来维持其现状 ${ }^{22}$ 。

此外, 在探讨加藤弘之的宗教观时不得不提的一点是他对于神道的态度。既然 一切宗教都是迷信, 都是与国家、科学互不相容的, 加藤弘之就必须针对明治时期 国家的统治意识形态一国家神道给出合理的解释。神道到底是不是宗教？加藤弘之 在对这个问题的回答上显得非常模糊。他曾经在《国家学会杂志》上发表过一篇题 为 “国家与宗教的关系” ${ }^{23}$ 的文章, 在其中承认神道是宗教, 但是一种有别于佛教、 基督教的 “不发达的宗教”。他指出, 日本的神道原本是为了对天皇的祖先或平民当 中对社会有过功劳的人表示尊敬而进行的一种祖先祭祀活动, 在维新以前不能将其 作为宗教来看待。维新以后逐渐发展出诸如宗旨教义等一些宗教要素, 但远远不及 佛教、基督教的教义发达, 也没有传教、丧葬仪式等宗教行为。因此, 他主张神道 复古, 使之回归到以前的传统状态, 作为超越于一切宗教的存在。但值得注意的是, 他提出这种主张的理由是担心神道这种 “不发达的宗教” 会受到佛教和基督教的威 胁，从而给日本的国体和皇室权威带来消极的影响 ${ }^{24}$ 。

综上所述, 加藤弘之基于他所倡导的进化论思想, 为自己的宗教批判提供论证 依据, 以他所谓的一种 “科学的方法” 从国体论角度批判了宗教的有害性, 从哲学 角度证明了宗教的非科学性。可以说他之所以持有这种绝对主义式的宗教观, 进化 论思想在一定程度上起到了重要的影响。进化论的思维方式使他形成了 “宗教是与 科学相对立的迷信” 的观点, 也决定了他的着眼点始终在于 “国体”，对宗教的是非 判断要以维护人类社会现阶段进化的最高形式一 “国家” 的统治基础为前提; 同时 他对宗教持有的绝对否定态度也让自己在解释神道合理性的问题上陷入了两难境 地。由于加藤弘之的宗教观没有超越意识形态的控制, 因此他既无法从完全客观的 立场出发来审视宗教、对神道的性质进行明确的定位, 针对宗教现状也没能提出行 之有效的措施, 具有明显的局限性。以上阐述了加藤弘之的宗教观及其实质, 接下 来分析他对基督教和佛教的批判中所蕴含的进化论思想。

22 “将来的宗教” 没有创立的必要, 也不具备存在的理由, 宗教维持现今的状态足矣。” 同上, 第 218 页。

23 加藤弘之:「国家と宗教との関係」, 『国家学会雑誌』, 国家学会事務所, 1890 年, 第 4 卷, 第 44 号。

24 “在神佛耶稣三教中, 神道作为宗教是最薄弱的, 理所当然会受到佛教和耶稣教的压制, 这与日本 的国体之间有着非同小可的关系。(中略) 因此我建议将神道恢复到过去的状态, 作为一种超然于 宗教之外的存在, 这样就不会受到佛教和耶稣教的压制, 也可以保证皇室统治的安全。”同上, 第 552 553 页。 


\section{3. 加藤弘之的基督教批判}

加藤弘之对基督教的批判由来已久, 最早要追溯到他 “转向” ${ }^{25}$ 之前的明治 2 （1869）年，在当年出版的小册子《交易问答》中，他吐露了自己对基督教的厌恶 之情 ${ }^{26}$ 。另外在后年的回忆录 “文学博士加藤弘之君” 中, 他提到自己从年轻时代学 习西方思想之时起就对耶稣教 “不是很感冒”, 因此转而开始涉猎哲学、道德、政治、 法律等领域的书籍 ${ }^{27}$, 可见加藤弘之从思想形成期开始就是一位不折不扣的反宗教人 士。明治 32 (1899) 年, 出版 《天则百话》, 收录了 “关于基督教对偶像崇拜的禁止”、 “再论信教自由”、“孔教与佛耶教”、“耶稣的伦理” 等批判基督教的文章。 ${ }^{28}$ 其中在 “孔教与佛耶教” 的开篇, 加藤弘之提到:

吾人既然在此现实社会中生存行动, 那么最能够指导吾人的生存行动并让吾人 在达到利已的基础上有利于他人和社会的宗教才是善教。试问孔佛耶三教中哪一教 最适合此目标的实现? 余不得不回答，当然是孔教。 ${ }^{29}$

他以此为据, 批判基督教轻视现世社会、只注重死后世界、贬低肉身、片面鼓 吹灵魂救赎的教义，与强调 “忠孝仁义”、“修身齐家治国平天下”，关注现世社会和 人的身心道德修养的儒教相比不利于社会发展。加藤弘之判断三教孰优孰劣的标准 - “现实社会的生存行动” 的观念很明显来自于进化论的 “生存竞争” 思想。“利己 利他” 的说法与进化论也是紧密相连、表里一体的关系 ${ }^{30}$, 他认为有机体具有 “利已 的根本动向”, 这种 “利已的根本动向” 促发生存竞争、自然淘汰, 然后从 “利已的

25 明治 12 (1879) 年及次年, 加藤弘之相继发表演说草稿「天賦人権ナキノ説並善悪ノ別天然二アラ サルノ説」、「天賦人権ナキ論ノ続キ」, 明治 14（1881）年, 向当局提出将自己之前的著作『真政 大意』、『国体新論』绝版, 进而于明治 15（1882）年出版『人権新説』, 彻底否定了自己以前一直 主张的天赋人权思想, 并从进化论的立场对天赋人权思想展开猛烈的攻击, 在当时的思想界引起轩 然大波。后来日本学界将此事件通称为 “加藤弘之的 “转向””。松本三之介: 『日本政治思想史概 論』, 勁草書房, 1975 年, 第 136 138 页。

26 “耶稣教实在是一种可恶的东西, 对我皇国大有害处。”引自吉村道男:「明治末年におけるキリス 卜教排撃論一特に加藤弘之を中心として」, 『国史学』(72・73), 国史学会, 1960 年, 第 194 页。

27 加藤弘之:「文学博士加藤弘之君」, 吉田曠二: 『加藤弘之の研究』, 大原新生社, 1976 年, 第 256 页。

28 日文原题为「基督教の偶像拝礼の禁に就て」、「再び信教自由に就て」、「孔教と仏耶教」、「耶蘇の 倫理」, 收录于『天則百話』, 博文館, 1899 年。

29 加藤弘之:「孔教と仏耶教」, 同上, 第 205 页。

30 “之前粗略提到过, 余的新主义 (即 “转向” 之后的思想一笔者注) 完全来自于进化主义, 而进化 主义可以归结为一元主义、必然主义、因果主义。(中略) 余的利己主义完全来自于上面提到的一 元主义、必然主义、因果主义 (即进化主义一笔者注)”。『加藤弘之自叙伝』, 加藤弘之先生八十歳 祝賀会編集，1915 年，第 50 51 页。 
根本动向中” 衍生出 “利他”, 即 “进化了的利已”, 通过利已和利他的结合才能推 动社会的进化发展。 ${ }^{31}$ 因此, 加藤弘之的结论可以解释为, 基督教既不能给处于生存 竞争、优胜劣汰社会中的人提供积极的指导, 也不能实现以进化论为基础的 “利已 利他”, 推动社会的进化发展。

加藤弘之真正对基督教展开实质性的批判是从明治 40（1907）年开始, 此后的 三年之间, 他相继写就《吾国体と基督教》、《迷想的宇宙观》、《基督教徒穹す》三 部著作，然后于明治 44（1911）年将这三部著作汇集成一部，以《基督教の害毒》 为题再度出版。他的基督教批判遭到以基督教人士为首的各方面质疑和反驳, 引发 了一场大规模论争。《吾国体と基督教》主要论证了基督教的迷信性以及对日本国体 的害处, 针对各方人士对此书的质疑和反驳, 他从多达 30 种的驳论中选取了 16 人 的文章收录于《迷想的宇宙观》, 一一进行了回击, 并在文末向基督教徒提出两个尖 锐的问题 ${ }^{32}$ 。刊行半年之后, 见基督教阵营一方没有给出有说服力的解答, 于是加藤 弘之趁热打铁地出版《基督教徒窮す》, 在重申自己历来观点的同时, 宣告了自己在 这场论争中的 “完胜”。以下, 从反驳一方中选取两篇比较有代表性的驳论, 从进化 论的角度来探讨一下双方围绕基督教展开的论争。

\section{1 与日本組合基督教会牧師海老名弾正的論争}

海老名弹正的驳论发表在杂志 《太阳》第 13 卷第 13 号 ${ }^{33}$ 上, 题为 “读加藤博士 的 “吾国体与基督教”（加藤博士の『吾国体と基督教』を読む）”。海老名对加藤弘 之宗教批判的评价是, “数十年如一日地固守进化论, 实乃稀有现象。但处于思想急 剧变化、新事实不断发展的当今时代, 不仅固步自封, 也不是科学者应有的态度”, 并质疑 “加藤氏的唯物进化论与日本的国体是否果真一致契合”。海老名对加藤的质 疑针对很多方面, 其中涉及进化论的问题主要有两个: 一、皇室的由来。加藤博士 是进化论者, 所以不仅要相信人类和民族在历史上的进化, 也要相信动植物的进化。 这样看来，他也应该毫不怀疑地相信日本民族的祖先一换言之皇室的祖先也是经时 代变化从下等动物进化而来, 绝非天津日嗣或神孙, 而是动物的子孙。这项科学研

31 加藤弘之:「自然と倫理」, 『加藤弘之文書』第三卷, 同朋舎, 1990 年, 第 519 521 页。

32 其中的第一问是 “如果神是宇宙的本体, 全知全能又通晓情意、拥有至仁至爱的大德, 为何自然界 还会存在 “动物和人必须以与自身属于同一有机体的动植物为食才能生存” 的残忍现象”, 很明显 加藤弘之是在通过进化论的生存竞争理论来支持自己的观点。「迷想的宇宙観」, 『基督教の害毒』, 金港堂, 1911 年, 第 319 页。

33 海老名弾正:「加藤博士の『吾国体と基督教』を読む」, 『太陽』第 13 卷, 第 13 号, 博文館, 1907 年。 
究的成果与来自日本的口传古书中的国体论有天壤之别, (加藤博士) 的结论是通过 怎样的研究得来的; 二、民族宗教与世界宗教。加藤博士认为民族宗教与日本的国 体不矛盾, 但如果是世界宗教, 不管是基督教还是佛教, 都肯定与国体存在冲突, 这是没有仔细研究过进化理法的谬说。加藤博士是进化论者, 应该承认进化的理法 同样适用于国家和宗教。日本古来的民族宗教随着当今日本帝国的发展, 已经逐渐 失去了势力, 基督教和佛教却在不断壮大。按照进化的理法来看, 可以解释为日本 帝国已经超越了民族宗教的时代, 正在朝着世界宗教的时代进化。这是民族的进化、 国民的进化, 但凡相信进化论的人, 不能不注意到这一点。加藤博士作为一名进化 论者提出的论点委实令人惋惜。

海老名弹正的反驳可谓翟中了加藤弘之的要害, 他以其人之道还治其人之身, 用对方最引以为豪的进化论思想来批驳了其论点。他痛斥加藤弘之的进化论思想与 日本的国体根本不相符, 加藤的论说不是以科学研究为依据的, 对进化论的肤浅理 解证明其不是一个合格的进化论者。不过海老名的驳论明显带有维护基督教的情绪 色彩, 这与他身为基督教徒的宗教立场是分不开的。对此, 加藤弘之的反论则显得 有些力不从心。针对皇室的由来问题，他回答:

余虽是进化主义者, 但决无在余的国体论中引入 《物种起源》的必要, 余讨论 的只是人类世界的吾国体。余也不是盲信古传说和神话的人, 然而吾皇室自有史以 前开始就一直是一脉相承, 这是任何人都无法否定的, 我相信恐怕海老名牧师也没 有足够的根据对此提出异议。 ${ }^{34}$

很明显加藤弘之没有正面回答海老名弹正的质问, 更没有能够提供出科学根据 来证明皇室来源于何处, 而只是一味地重复自己之前的观点。至于第二个问题, 甚 至闭口不谈。

\section{2 与東洋大学教授広井辰太郎的論争}

广井辰太郎在《六合杂志》第 $325^{\sim} 327$ 号 ${ }^{35}$ 上连续刊登题为 “吾国体与基督教评 论 (吾国体と基督教評論) ” 的文章对加藤弘之提出质疑, 其驳论与海老名弹正相比 更加客观公正一些。首先他认可加藤弘之以因果律即自然法为依据的世界观, 称其 “条理井然, 贯穿着科学精神”。对于加藤 “民族宗教只限于一国国民, 性质相对劣 等, 经逐渐进化才到达了高尚开明的宗教即世界宗教的领域” 的说法, 高度评价其 “体现了进化论者的风采”。在涉及进化论的问题上, 广井的质疑主要包括：一、宗 教的超自然世界观。加藤强调佛耶二教的超自然世界观与科学的自然世界观不相容,

34 同 32, 第 94 95 页。

35 広井辰太郎:「吾国体と基督教評論」, 『六合雑誌』第 325 327 号, 警醒社, 1908 年。 
这是因为他只着眼于旧式的宗教观念, 而忽略了现今的宗教观念。如果从进化论的 角度来说, 宗教也是在不断进化的, 加藤以旧式宗教观念中存在的超自然世界观来 断定现今宗教的立场全部是超自然的, 原因在于他缺乏对现今宗教的全面了解, 没 有意识到现今的神学理论远比他想象的要进步得多; 二、国体论。加藤从理论上对 宗教的批判不失一个科学者的风范, 但与此相比他在国体论的角度上下了更多的工 夫。紧接着广井列举了一系列历史事实来证明加藤弘之所主张的国体论其实与进化 论并不能同时成立; 三, 国家权力。加藤认为国家是至高无上的, 没有比国家权力 更大的权力, 然而当时世界上召开的诸如和平会议 ${ }^{36}$ 就是为了在国与国之间规定一种 高于国家的权力来约束某些国家的行为, 因此从进化论的角度来看国家的权力并非 权力进化的最高阶段。广井批判加藤弘之试图通过极端的利己主义、因果论和过激 的生存竞争论、进化论来把日本的国体打造成一种特殊的存在。

广井辰太郎的驳论与海老名弹正的驳论有相似之处, 比如都是通过自己对进化 论的理解来批驳加藤弘之的进化论, 都强调加藤的进化论思想与日本的国体并非完 全一致, 但广井的侧重点主要在于国体。他批评加藤在论述宗教、道德等各种问题 时敏锐冷静, 可是一旦涉及到与日本国体的关系时, 就陷入了毫无科学根据、违背 常识的独断论中。相比海老名弹正, 广井的文章有大量的历史事实做支撑, 更具说 服力, 其态度也更加客观公正一些。

加藤弘之针对广井的质疑一一做了回应, 其中关于第二个问题, 他认为进化论 与日本的国体根本不矛盾。他的辩解是 “余相信人类的进化, 所以不意味着只有日 本民族是例外的特殊民族。但余相信日本民族的国体是完全特殊的，人类进化的由 来与民族的国体完全不是一回事”, 进而又解释道 “日本是以天皇为宗家、国民为臣 子的立宪制族父统治国家, 因此从这个意义上来说日本的国体与一般自然界的进化 论毫无关系。余虽相信一般自然界的进化, 却没有必要拿这种理论来解释国体, 国 体论是日本民族产生以后才出现的”。在笔者看来, 加藤的驳论不仅毫无逻辑、自相 矛盾, 并且有些强词夺理。他既没有举出丝毫的论据来证明 “进化论与国体不存在 冲突”, 还片面强调日本国体的特殊性, 否认了自己一直坚持的进化论的普适性。

\section{4. 加藤弘之的佛教批判}

加藤弘之的佛教批判与他的基督教批判相比要温和得多, 因为他认为佛教虽于 日本的国体有害，但毕竟传入日本的时间长久，已经充分被日本同化而变为了日本

36 此处指的是 1907 年在荷兰海牙召开的第二届万国和平会议, 会议就限制军备、国际仲裁等问题进 行了讨论。 
式的佛教 ${ }^{37}$; 并且从历史来看, 佛教确实促进了日本古代文明的开化。此外他还认为 佛教具有一些哲学特质, 蕴含着深刻的道理, 比基督教或回教等 “浅薄” 的宗教有 更多可取之处。 ${ }^{38}$ 因此正如吉田旷二所指出的, 加藤弘之对佛教的批判是不彻底的 ${ }^{39}$, 多少带有一些同情的色彩, 这一点可以从他后期发表的关于佛教的文章中看出 ${ }^{40}$ 。整 体来看, 加藤弘之对佛教的批判同样是从与日本国体的关系和教理两个角度来展开 的。关于前者, 比如在以《吾国体と基督教》为首的多部著作或论文中论述了佛教 的世界宗教性质与日本国体的矛盾, 与对基督教的批判如出一辙。在教理方面, 主 要针对佛教的善恶因果报应论进行了批判。以下以教理为重心, 从进化论的角度来 分析加藤弘之对佛教善恶因果报应论的批判以及佛教界人士的驳论。

明治 28（1895）年，加藤弘之在《哲学杂志》第 100 号上发表题为 “佛教所谓 的善恶因果报应并非真理” ${ }^{41}$ 的文章, 将佛教的善恶因果报应论与社会的善恶因果报 应论加以区分, 批判了前者的谬误。他认为, 佛教主张道德的善恶邪正之分以及善 因得善果、恶因得恶果的因果报应论是由于佛教相信天地间自然存在着对道德的善 恶邪正进行裁夺赏罚的 “自然力”, 而这与自己历来主张的 “天则” ${ }^{42}$ 相互违背, 是 一种完全的谬论。因为道德本来在天地之间是不存在的, 而是在产生了人类社会之 后, 为了维持社会的发展而逐渐进化出来的 (多少借助了人力, 即人依靠自己的主 观判断制定出来的）判断人类行为的标准。世间万物的生灭消长、祸福吉凶, 其背 后虽然都存在着必然的因果联系，但这种因果联系指的是 “社会的因果报应”，与佛 教的因果报应的本质区别在于它不承认道德的善恶之分是自然存在的, 善因未必带 来善果, 恶因未必招致恶果, 判断道德的善恶邪正关键在于是否合乎天则。佛教认 为善恶的因果报应早晚必然会发生。但其实社会的因果报应不一定会发生，并且对 道德善恶的判断标准也会随着社会的进化而发生变化。由此可知, 加藤弘之以他所 坚持的因果主义为依据, 认为宇宙中只存在“社会的因果报应 (换句话说就是天则)”, 批判佛教善恶因果论的 “荒谬性”, 否认了道德的自然存在, 认为道德是人类社会进 化的产物, 并且也会随着社会的进化而不断变化。前文已经论证过, 加藤弘之认为

37 同 23 , 第 551 页。

38 同 21 , 第 205 页。

39 同 9, 第 151 页。

40 例如在明治 44 (1911) 年发表的文章「仏教の現在及び将来に就いて」(『学説乞正袋』, 弘道館, 1911 年）中, 加藤弘之慨叹当时佛教界人士的堕落状况, 提出多点建议来呼呼佛教的改良。

41 日文原题为「仏教に所謂善悪の因果応報は真理にあらず」, 『哲学雑誌』第 100 号, 哲学雑誌社, 1895 年, 后收录于『講演全集』第二册。

42 “所谓 “天则” 是 “天然法则” 的简称, 是英文 'Natural law (自然法)' 的译词。宇宙间存在的 万事万物无不受天则的支配。”「天則」, 『講演全集』第一册, 第 1 页。 
自己所坚持的因果主义是经进化论证明过的 “科学真理”, 因果主义与进化主义是表 里一体、相辅相成的关系 ${ }^{43}$, 因此我们可以认为进化论在他对佛教善恶因果报应论的 批判中起到了一定的作用。

对于加藤弘之的批判, 佛教界马上给予了回击, 杂志《佛教》和《禅宗》成为 了这次论争的主要根据地。一位署名 “大久保昌南” 的佛教界人士在《佛教》杂志 第 104 号 $^{44}$ 上发表文章辩驳, 一、加藤弘之将一般意义上的善恶观念与具体的善恶行 为混为一谈。具体的善恶行为根据时代和社会的不同会有所变化, 但一般意义上的 善恶观念是本来就存在的, 因此佛教承认自然存在善恶观念的主张是正确的。换句 话说, 判断一般意义上的善恶正邪的道德不是社会进化的产物。二、另外对于佛教 来说, 对善恶的定义是以 “一切众生界” 为前提, 与加藤弘之以 “社会” 作为评判 标准的做法不在一个层面, 因此有利于社会进步的善和不利于社会进步的恶在佛教 中要以 “一切众生界” 为标准, 有利于 “一切众生界” 的进步才是善, 反之是恶。 即便如进化论者所说，人类社会的发生具有一定的起源，但众生界是 “无始以来的 存在”，因此建立在无始以来存在的众生界上的善恶邪正也是无始以来存在的，因而 也是先于人类世界存在的。进化论在一定程度上是真理, 但不能以此为依据来解释 宇宙中存在的所有事物。总而言之, 大久保的结论可以归为两点：一、加藤弘之混 淆了一般意义上的善恶观念和具体的善恶行为; 二、加藤弘之用进化论的观点来批 判佛教的善恶因果报应论，但进化论并非放之四海而皆准的真理。

针对大久保的第二个问题, 加藤弘之再次从进化论的角度予以了反驳。他将自 然界分为有机界和无机界, 认为佛教所说的众生界是自然界中的有机界的一部分, 有机界中的人类从进化角度来讲是最高等的生物。但构成有机界的成分一有机物不 是原本就有的, 而是由无机物演变进化而来, 这是生物进化论证明过的真理。因此, 作为有机界一部分的众生界也不是原本就存在的, 所谓一切众生无始以来存在只是 佛教徒自己所相信的说法。即便从无始以来存在有机物, 但认为在人类社会形成 (人 类的产生是各种有机物中最晚的）以前便存在只有人类才需要的道德善恶的说法简 直是天方夜谭。45

43 ““因果” 指的是推进进化的 “原因与结果的必然连锁” ” 『自然界の矛盾と進化』, 第 8 页。此外, 日本学者金子洋子也在论文「加藤弘之と仏教一その因果応報説批判を中心に一」中论证了加藤弘 之批判佛教善恶因果报应论的理论基础在于他的进化论思想。二葉憲香編:『続国家と仏教 近世 近代編 (日本仏教史研究 4)』, 永田文昌堂, 1981 年, 第 124 页。

44 大久保昌南:「加藤博士の『仏教二所謂善悪/因果応報八真理ニアラズ』てふ論に就ひて」, 『仏 教』第 104 号, 日本仏教協会, 1895 年。

45 加藤弘之:「余が善悪因果応報論に対せる『仏駁』雑誌の駁論を読む」, 『講演全集』第二册, 第 98〜99 页。 
《禅宗》杂志在第 8 号上刊登无署名文章 ${ }^{46}$, 反驳如下: 加藤博士所谓的天则在 佛教中有着对应的概念一真如。佛教认为 “真如的理本身非善非恶, 合乎真如的行 为是善, 违背真如的行为是恶”, 这与加藤博士主张的 “天则中本不存在道德和善恶 邪正” 的说法是一致的。既然善恶邪正的判断标准在于是否合乎自然的真理即所谓 的天则, 那么冊宁说善恶邪正本来就存在于天地自然之中, 而绝非在人类组建社会 后才出现。并且因果报应要按照天则来裁夺, 如果按照加藤博士的说法, 善恶与祸 福厉害全无关系的话, 那岂不是说明根本就不存在因果的理法。《禅宗》杂志的这篇 文章把佛教的 “真如” 等同于加藤弘之的 “天则”, 从而将以真如为标准来判断的 “善 恶” 与加藤弘之以天则为标准来判断的 “善恶” 等同起来, 认为佛教在惩恶扬善上 “大有裨益”。其根本目的无非在于证明佛教中的 “善恶因果报应” 是自然存在的。

对此，加藤弘之批判《禅宗》杂志的文章混淆了 “人类界” 和 “自然界” 的概 念。道德上的善恶之分只存在于人类界, 而自己所说的是自然界本来不存在道德善 恶、因果报应。因此符合天则的善在人类界中未必是善, 违背天则的恶在人类界中 也未必是恶。 ${ }^{47}$ 此处, 加藤弘之再一次否定了进化论的普适性, 为了自圆其说, 他强 词夺理地声称 “天则” 是自然界的概念, 认为其不适用于人类社会。由此就会推出 如下的结论, 即进化论的理法只能用来解释外在于人类社会的自然界中发生的现象, 而这与他一向推崇的社会进化论明显是相互矛盾的。

\section{5. 结论}

以上通过考察分析加藤弘之的宗教批判以及他和以宗教界人士为首的学者之间 展开的论争, 论述了进化论思想在当中发挥的作用和影响。总体来看, 进化论的思 想在很大程度上左右了加藤弘之对宗教的判断, 决定其持有彻底的宗教否定态度, 并在他与其他学者和宗教人士的论争中扮演了重要角色, 是论争的焦点问题之一。 支持基督教和佛教的学者或宗教人士也或多或少地根据自身对进化论的理解, 在对 加藤弘之进行反驳时利用了进化论的观点。可以说进化论既是加藤弘之对宗教教理 进行批判的重要理论根据, 同时由于其对进化论的肆意解释和主观臆断, 也被反对 方以 “缺乏科学精神” 为由, 拿来作为反驳自己的工具。不过无论如何可以肯定的 是, 明治时期的进化论一方面作为 “科学” 的代名词, 被很多人视为是与宗教相对 立的概念, 而迫使思想家们必须摸索如何处理二者之间的关系。同时也作为席卷明 治思想界的重要西方理论发挥了深远的社会影响, 被各种不同的思想流派、不同意 识形态的群体用作为自身的观点学说作辩护的工具。而一种思想是否能对社会充分 发挥积极作用, 促进社会的发展, 关键并不在于思想本身, 而在于这种思想如何被 人们所认识和利用。

46 「加藤博士の非因果応報論」, 『禅宗』第 8 号, 貝葉書院, 1895 年。

47 加藤弘之:「同上に対せる禅宗雑誌の駁論を読む」, 『講演全集』第二册, 第 106～107 页。 


\section{参考文献}

『小崎全集』 小崎全集刊行会 1938 年

Peter J. Bowler 著、鈴木善次ほか訳 『進化思想の歴史』 朝日新聞社 1987 年

『明治文化全集』第 11 巻（宗教編） 日本評論社 1928 年

『明治文化全集』第 27 巻（科学編） 日本評論社 1967 年

『内村鑑三全集』第 27 巻 岩波書店 $1980 \sim 1983$ 年

吉田曠二 『加藤弘之の研究』大原新生社 1976 年

田畑忍 『加藤弘之』吉川弘文館 1959 年

永田広志 『永田広志選集第四巻 日本哲学思想史』 白揚社 1948 年

加藤弘之『吾国体と基督教』 金港堂 1907 年

加藤弘之『自然界の矛盾と進化』金港堂 1906 年

『加藤弘之講演全集』丸善株式会社 1900 年

松本三之介 『日本政治思想史概論』 勁草書房 1975 年

『加藤弘之自叙伝』 加藤弘之先生八十歳祝賀会 1915 年

『加藤弘之文書』 同朋舎 1990 年

『基督教の害毒』 金港堂 1911 年

『学説乞正袋』弘道館 1911 年

金子洋子「加藤弘之と仏教一その因果応報説批判を中心に一」『続国家と仏教 近世・近代編（日 本仏教史研究 4)』 永田文昌堂 1981 年 